\title{
Um olho aberto na noite: em torno dos fotogramas de Éric Rondepierre
}

\section{OSVALDO FONTES FILHO}

\section{Resumo}

Este artigo ressalta alguns engajamentos da linguagem fotográfica de Éric Rondepierre, artista particularmente concernido pelas metamorfoses da imagem em razão da usura do tempo no dispositivo cinematográfico. Seu trabalho de arquivista e arqueólogo dos fotogramas, essas imagens congeladas dos filmes, tem configurado nos últimos 30 anos uma surpreendente visualidade ancorada no espectral, no híbrido e no descontínuo. Ao narrar a travessia iniciática de um sujeito do olhar pelas materialidades da imagem fílmica, o romance La Nuit Cinéma (2005), ficcionalização de seu fazer artístico, presta-se aqui a balizar um percurso por seus motivos mais significativos: o limite, o desvio, o acaso, o vazio, operadores de uma latência que ajuda a repensar as eficácias do visual e os mecanismos do imaginário em tempos de um contínuo fluxo narrativo.

Palavras-chave: Fotografia, Cinema, Éric Rondepierre. 


\title{
One eye open at night: around Éric Rondepierre's frames
}

\author{
OSVALDO FONTES FILHO
}

\begin{abstract}
This paper emphasizes some of the engagements of the photographic language of Éric Rondepierre, an artist particularly concerned with the metamorphoses of the image through the time in the cinematographic apparatus. Rondepierre's work as an archivist and archaeologist of photograms, these frozen images of a film, has shaped in the last 30 years a surprising visuality anchored in spectral, hybrid and discontinuous figurations. In narrating the initiatic journey of a viewer looking for the image-matter of films, his novel La Nuit Cinéma (2005), a fictionalization of his artistic making, serves in this study to carry out an investigation of its most significant elements: limit, deviation, chance, emptiness, operators of a latency that helps to rethink the efficacies of the visual and the mechanisms of the imaginary in times of an uninterrupted narrative flow.
\end{abstract}

Keywords: 


\title{
Un ojo abierto en la noche: alrededor de los fotogramas de Éric Rondepierre
}

\author{
OSVALDO FONTES FILHO
}

\section{Resumen}

Este artículo resalta algunos acoplamientos del lenguaje fotográfico de Éric Rondepierre, artista particularmente referido por las metamorfosis de la imagen en razón de la usura del tiempo en el dispositivo cinematográfico. Su trabajo de archivista y arqueólogo de los fotogramas, esas imágenes congeladas de las películas, ha configurado en los últimos 30 años una sorprendente visualidad anclada en el espectral, en el híbrido y en el discontinuo. Al narrar la travesía iniciática de un sujeto de la mirada por las materialidades de la imagen fílmica, la novela La Nuit Cinéma (2005), ficcionalización de su hacer artístico, se presta aquí a balizar un recorrido por sus motivos más significativos: el límite, la desviación , el azar, el vacío, operadores de una latencia que ayuda a repensar las eficacias del visual y los mecanismos del imaginario en tiempos de un continuo flujo narrativo.

Palabras clave:

Fotografía, Cine, Éric Rondepierre 
"Necessito do escuro, necessito nada ver para avançar. Não sei para onde vou, mas aprecio essa cegueira". "[Os fotogramas], esses espiões locados em território inimigo..."

Éric Rondepierre

"Poética de uma metamorfose: na solidariedade inesperada da imagem e de seu corpo, o que cegava a visão acede ao visível; a decomposição parece advir no seio do mundo representado."

Daniel Arasse

"Os fotogramas são as únicas imagens reais e as únicas imagens invisíveis em um filme. Este é o paradoxo ontológico que faz com que os fotogramas sejam os 'pontos cegos' do cinema".

Philippe Dubois

\section{Uma heurística junto ao fotograma}

Éric Rondepierre é um artista da fotografia singularmente marcado pelo empenho obsessivo em surpreender o que expõe o olhar a suas insuficiências. Voyeur impenitente, como ele mesmo se confessa, interessa-se por uma intimidade própria das imagens a se mostrar em certa clandestinidade, nos bastidores por assim dizer de um olhar saturado de insidiosos protocolos de regulação. Assim, uma freqüentação voluntariamente ametódica da cinemateca leva-o a preterir as evidências da imagem sequenciada em favor dos micro-acontecimentos da usura que a paralisam ou que a prometem à deterioração em uma deliquescência 
ácida. Rondepierre é um frequentador dos fotogramas envelhecidos, esses testemunhos dos tumultos desordenados da materialidade da imagem; ele é um fotógrafo da realidade-película em processo de evanescência e desfiguração. Modo, diz-ele, de "surpreender os filmes em sua intimidade", de "trabalhar em seus limites", em seus "limbos", na "periferia, esse estado limite do fim e do começo das coisas onde tudo bascula" (RONDEPIERRE, 2001, p. 67, 42). Viceja, aqui, um percurso imperativo: da imagem propriamente ao corpo da imagem, da transparência do signo à opacidade da matéria. "Era preciso que abrisse os olhos para minha cegueira", confessa Rondepierre (2003 apud CARON, 2004, on-line), "que saisse do espetáculo pelo negrume". Estranho voyeur, pois, como estima Daniel Arasse (2003, on-line), que procura deliberadamente pelos "lugares da cegueira" de modo a se furtar aos efeitos do cinema, verdadeiros "entraves à estratégia escópica” (RONDEPIERRE, 2001, p. 51).

Tal deambulação, à margem dos feixes de luz crua das imagens consensuais, põe em pauta uma particularíssima heurística da imagem. Rondepierre trabalha com fotogramas resgatados ao invisível de seus $1 / 24$ de segundos, como tecidos celulóides de ruptura e de disfuncionamento na película: telas em preto, parasitárias, a entrecortar com seu negrume a narrativa fílmica; ou então figuras amorfas sobre as quais as palavras/letreiros se desvelam em fragmentos que fazem aparecer na casualidade mesma do corte um diverso sentido, ou melhor, seu desvio em jogos semânticos de derrisória ironia. Por vezes, uma imagem é construída pela sobreposição de dois fotogramas extraidos da narrativa anódina de um anônimo filme pornográfico, modo de interceptar no lugar de uma "pobreza estética, expressiva, informativa" o que o artista denomina a "coisa mesma" (RONDEPIERRE, 2005a, p. 131).

Fato é que o recorte, o congelamento e/ou a sobreposição, atos de um único esforço de decomposição, ou de recomposição, resultam em uma circulação enviesada do olhar, que não mais atravessa a imagem em busca do referente: as partes se autonomizam em suas singulares plasticidades, assim como as perspectivas tendem à implosão, como bem observa Berthou Crestey (2011, on-line). Levam com elas o contínuo narrativo. A "imagem como tal", sustenta Rondepierre (2001, p. 75), é constituída do casamento entre "a narrativa de menos [...] e o fato material", assumido em sua intensidade figural. $\mathrm{O}$ que assim se ilustra é uma figurabilidade próxima 
de uma incursão onírica (ARASSE, 2003, on-line). No mais, tais imagens passam por ser o resultado do que Rondepierre diz ser uma "compulsão voyeurista matizada de certo prazer transgressor", fonte de um trabalho de recolhimento de formas clandestinas, "adormecidas em terra inimiga", à espera da ordem para "descolar do quadro que esposaram por tanto tempo para agir contra ele". Encontramo-nos, pois, próximos do que tem motivado, desde os anos 80 , a criação e a poética em torno do gênero found footage: compor "Objetos Visuais Não Identificados" suscetíveis de "exumar" nas imagens a potência do sonho a fim de escapar àquela construção do olhar dita outrora "legítima" que entendia nos constranger a "perceber o mundo a partir de um único ponto, coincidente com nossos órgãos visuais, com nosso corpo" (RONDEPIERRE, 2005a, p. 135-136).

O fotograma assim tomado como instância de sobredeterminação não mais remete à noção de limite temporal. Advindo de uma prática de extração, de corte na fluidez da narrativa fílmica, ele é antes da ordem do desvio, como observa Rodriguez Ferreira (2008, p. 584). Corresponde, pois, ao que a ficção registra como uma "sensibilidade aos limiares, aos limites, àqueles momentos fugazes em que a identidade das coisas vacila" (RONDEPIERRE, 2010, on-line). O olhar vigilante do fotógrafo empenha-se em desvelar o potencial "divórcio perceptivo" de imagens latentes, "em sofrimento" por detrás de suas evidências de oficio. Protagonistas de uma heurística que não deixa de se assemelhar a uma exumação, essas imagens evocam "olhos fechados que abarrotam nossas lixeiras e arquivos, no aguardo de serem abertos". Transfiguradas pelos vieses sinuosos de um olhar de noturna perspicácia, as figuras exumadas das cinematecas por Rondepierre multiplicam zonas de indeterminação, põem à prova nossa (com)pulsão escópica, afeita desde sempre à transparência retórica - a imagem submetida ao processo verbal de uma narrativa - a que nos habituou o cinema e a fotografia (ARASSE, 2003, on-line). A tal processualidade corresponde a uma redisposição dos termos e dos lugares: "a imagem não está mais sobre um suporte”, esclarece Rondepierre (2001, p. 6o), "mas o suporte, o material é apreendido na imagem, trabalha-a do interior. Encima-embaixo, diante-detrás, os planos se invertem, se misturam, tornam-se indecidíveis, ambíguos". Com pertinência, Arasse (2003, on-line) fala de uma "sensação de viscosidade espacial", de uma "inquietante movência do espaço", reforçada pelos ecos, permutas e des- 
locamentos instados a afetar as figuras de nossos aparatos mecânicos de fabulação.

\section{Uma negação da fábula cinematográfica}

Com La Nuit Cinéma, Rondepierre experimenta uma primeira incursão literária, uma ficção que de algum modo se presta a registrar os condicionantes de seu engajamento sui generis junto à imagem. Ali, como se lê na quarta capa, "misturam-se narrativa iniciática, autoficção e reflexões estéticas, em um romance refinado onde a guerra - conjurada pelo jogo, a fantasia e o humor - é o cenário de uma travessia da noite seguida de um hipotético retorno à luz: aquela do pós-cinema?" A interrogação, aqui, se justifica. Romance de um fotógrafo dos fotogramas, portanto dos interstícios (das bordas, das transições), o que ali se narra são os modos de suprimir o fluxo temporal das narrativas do cinema, sua ilusão transitória. Nessa negação da fábula cinematográfica, La Nuit Cinéma não deixa de ser um livro metafórico, verdadeira autobiografia do olhar e, por força de uma "obliqüidade maligna" (RONGIER, 2005, on-line), incursão no trabalho fotográfico de seu autor. Mas a narrativa é, igualmente, um alargamento de campo. A ficção é assumida por Rondepierre (2005b, on-line) como uma "forma integrativa" capaz de abrigar "a massa de coisas concretas drenadas pela procura de imagens" no imenso continuum da grande tela. O que privilegia, como lembra Dubois (1993, p. 5), uma operação de superposição: a fotografia na superfície, o cinema em profundidade, e a escrita como instância deslocada.

De imediato, a voz autoral caracteriza-se em sua gênese: o narrador fala do apelo precoce do cinema junto a uma sensibilidade à parte, nutrida na "noite das salas escuras", indulgente à "submotricidade alucinada do cinéfago". A imobilidade e a escuridão marcam, em adendo, um biografema revelador: o papel sui generis que o autor assumiu no teatro universitário de juventude, aquele de um morto, de um fantasma, personagem mantido incógnito em cena, "mergulhado no escuro a alguns centímetros da primeira fila", mas que se subtrai ao olhar dos outros. Prefiguração de sua condição de futuro artista do fotográfico, o papel que lhe fora reservado de um olhar que evolui por entre os demais atores sem ser notado, tal qual uma espectral figura que não participa da mesma temporalidade dos demais atores, prefigura a perfeição, o olhar do narrador que, em La Nuit Cinéma, "persiste 
em ver no escuro; [...] numa posição dissimulada, espécie de olho aberto na noite" (RONDEPIERRE, 2005a, p. 12, 14,15).

Páginas adiante, nova passagem autobiográfica atesta a precoce vocação às intermitências da escuridão. Obrigado nos tempos de certa indigência juvenil a se alojar em um sótão, junto a restos de "um interesse relativo", o narrador fala de "certa escuridão objetiva" que o envolve com carícia e voracidade, e que se prolonga na tela de um velho aparelho de televisão donde surgem "reflexos luminosos tomados da luminescência dos letreiros, pequenos blocos imóveis em suspensão no ar rarefeito", "fragmentos de frases" que dançam diante de olhos ávidos por tramar uma vingança contra o mundo a partir da "obscuridade dos filmes" (RONDEPIERRE, 2005a, p. 73).

A primeira exposição de Rondepierre como artista do fotográfico, em 1992, no Grand Palais de Paris, intitulava-se La Nuit DU Cinéma. O próprio autor justifica a eliminação da preposição no titulo de seu romance ulterior: cumpriria, agora, "tornar a noite consubstancial ao cinema". La Nuit Cinéma pode, pois, ser vista como uma vasta projeção onde as personagens e o cenário pertencem, a princípio, ao universo do fílmico. Ocorre que Rondepierre evita, como ele mesmo frisa (2010, on-line), "afogar o peixe da verdade nas águas turvas da ficção". É fato que seu romance não sobreinveste estilemas literários ou a construção psicológica das personagens. $\mathrm{O}$ que, de certo modo, permite aferir a contemporaneidade de sua construção ficcional. A narrativa é, antes, um documento em torno do trabalho do fotógrafo - somente enquanto tal, diga-se, ele aqui nos interessa -, mas que passa pela ficção em vista de "desviar", por assim dizer, documentos extraídos da ficção: "uma espécie de arquivo narrativizado", como o define seu autor (2005a, p. 16), mas que é tentado a se manter numa clandestinidade propícia à freqüentação de um onipresente "magma de noite informe".

La Nuit Cinéma é a narrativa de um homem que se refugia do mundo nos subterrâneos da guerra de etnias na ex-Iugoslávia, recrutado um tanto ao acaso a colaborar nos esforços de uma organização clandestina encarregada de salvaguardar o patrimônio fílmico ameaçado de desaparecimento junto com a fragmentação da unidade política daquela região da Europa. Aventura sinuosa ao sabor dos acasos da História, das histórias e das imagens de cinema. Narrativa de um mundo sempre limítrofe, entregue ao lusco-fusco das aparições, factício refúgio onde o latente (da imagem e 
do texto) é convocado ao primeiro plano. Nesse mundo em decomposição, o protagonista - ali absorvido "como um fotograma seguindo cegamente o coletivo das imagens de um filme" - observa "imagens em sofrimento" no mundo anônimo dos arquivos e, com elas, reaprende a olhar. Assim, por força de uma sensibilidade resgatada das facilidades das narrativas fílmicas, ele rompe com a missão "redentora" da organização secreta que integra, e descobre o valor supra documental dos fotogramas, documentos de um "congelamento das imagens", refreio das dinâmicas escópicas habituais. "As cinematecas são gigantescos asilos onde os filmes não cessam de agonizar": o credo do chefe da clandestinidade, fazer frente ao "buraco negro da memória ocidental", esbarra na personalidade niilista do narrador. À beira do abandono, levado pela indistinção entre imagem e realidade, ele passa a encarnar uma particularíssima heurística da imagem - e o consequente questionamento do ser das imagens -, heurística quiçá tão violenta quanto os acontecimentos da guerra que se prestam a cenário de fundo.

\section{Uma ficção figural da imagem}

Mais do que se prestar a algumas linhas indiscretas acerca das próprias obras fotográficas do escritor, essa heurística da imagem metaforiza o trabalho de um particular ficcional que se confessa desforra em relação ao real: trabalho de "deslocar, movimentar, mudar, multiplicar pequenas vidas no interior da grande, atravessar uma na outra, uma contra outra". Consequente tour de force da identidade, em escrita assumidamente autobiográfica, sob fundo de uma parábola do olhar:

[...] eu teria de mudar de nome, de figura. Do todo ao todo, de ninguém a Ninguém. $\mathrm{O}$ homem dos mil sortilégios se mascara, se desfigura, se altera até aos limites mais extremos. Eu o ajudava nesse jogo de ilusão, borrava-lhe os olhos, fazia-o ver o que eu o impedia de ver. Ele não mais sabia o que via, nem de onde via, nem o que era (pois ser é ver). Mas ele sabia aquiescer quando sua exaltação fracassava: seus olhos brilhavam e subitamente tudo lhe parecia real, infinito. (RONDEPIERRE, 2005a, p.117, tradução do autor).

Deter o fluxo das imagens; deslocar e magnificar, por assim dizer, fragmentos de visualidade anônimos: o gesto con- 
creto da tesoura sobre a película - regrado pela conveniência narrativa na mesa do montador, mas inapropriado numa cinemateca - adquire no romance de Rondepierre "dimensão material, simbólica, estética e dramatúrgica” (RONDEPIER$\mathrm{RE}, 2005 \mathrm{~b}$, on-line). O foto-grama - grafia que Rondepierre propõe para distinguir as imagens subtraídas das películas, de algum modo modificadas em sua reprodução fotográfica, dos fotogramas de filmes em geral - incorre na perturbação da temporalidade de nossa recepção estética, numa intromissão no automatismo escópico que toma as aparências por evidências. Trata-se de um modo de se imiscuir nos acidentes materiais da tela, esse lugar de projeção dos sonhos e das ficções contemporâneos. O artista-fotógrafo Rondepierre, analisa Denys Riout (2003, on-line), "sonha em pleno dia, diante da tela negra do cinema apreendido em sua essência". Sua persona literária, o narrador de La Nuit Cinéma, é acompanhada em seus atos de introspecção silenciosa da carne mesma do suporte imagético, aberta às metamorfoses mais suntuosas: modo de resgatar a imagem de seu lastro figurativo e narrativo.

Os foto-gramas de Rondepierre, ainda que no registro do ordinário e do insignificante, apontam obsessivamente para a ideia de desfiguração. Invariavelmente, é o rosto que se desfaz, ou melhor, as "imagens-rostos de filmes trabalhados pela mancha e pela trama que obliteram ou pacificam sua beleza pelo mistério" (DUBOIS, 2004, p. 233). Os foto-gramas são modo de desviá-las "de sua existência original, embalsamando-as na eternidade de uma imagem ex-posta, representando um gesto radical de arrebatamento". Razão porque Rondepierre (2004, p. 232) a elas se refere como "curiosas janelas", de contorno equívoco, "entre pródromo e lembrança”. Os foto-gramas são, ainda, operação de "desagregação intima do organismo semiótico e estético" da imagem, de modo a permitir "uma transferência imaginária do momento material sobre a própria representação" (LENAIN, 2003, on-line). Operação que, na interpretação de Dubois, refere diretamente à questão do ficcional:

Há anos, Rondepierre acua, nos velhos filmes, nitratos estragados, o que ele chama "acidentes da matéria”, manchas, inchaços, deformações, devorações químicas ou físicas, que afetam este ou aquele fotograma deste ou daquele pedaço de película, acontecimentos aleatórios que afetam o suporte e que ele expõe, assim, por eles mesmos, em ampliações 
suntuosas aonde os acidentes físicos da película vêm se inscrever como marcas do tempo na imagem, organizando com a parte figurativa combinações singulares, fulgurantes (o acaso as produziu) em que o estranho se mistura sutilmente ao poético. Eis a afirmação de um efeito de presença pela matéria que desemboca numa forma de ficção figural da imagem (DUBOIS, 2012, p. 113).

Os "ângulos cegos" do cinema, isto é, as zonas de não imagem ou, mais exatamente, as interferências acidentais entre a imagem e sua própria matéria endossam o modo de presença característico da imagem figurativa que elas desfiguram. A degradação material da película tem por consequência uma inegável perturbação da linha de partilha entre o fictício e o real. Razão porque a primeira imagem produzida por Rondepierre surge em seu romance descrita nos termos de uma fulgurância figural ( a se reter o emprego que Dubois preconiza da noção). Num velho filme comercial, o narrador conta ter surpreendido o rosto da atriz Joan Crawford (fig. 1), os olhos exorbitados e a boca asfixiada por seu próprio nome surgindo em legenda, mas ainda indecifrável pela interrupção do fluxo fílmico.

Tratava-se de um filme americano dos anos 40 ou 50, essa época abençoada na qual os filmes populares eram de uma incrível riqueza. Passei uma primeira vez a película em velocidade normal [...]. Uma personagem abre a janela: Joan Crawford, diz o texto que surge sobre a imagem. Passei então a fita uma segunda vez, parando o filme no instante precedendo de algumas imagens o surgimento do nome. Puxei a fita na mão, lentamente, quadro a quadro, de maneira que pudesse ver se formar uma grande mancha branca na parte inferior do rosto. Ali me detive. Na verdade, era o nome da atriz ainda ilegível. Mas aquele que não tivesse visto a fita teria se perguntado o que vinha fazer esse buraco branco de arestas bem desenhadas ali onde a atriz abria a boca. Joan Crawford, cujo olhar atônito o quadro congelado acentuava, via-se impedida de falar por força de seu próprio nome amalgamado na parte inferior da face. [...] A violência inapreensível em velocidade normal surgia de repente. Boca amordaçada, olhos esbugalhados, isso sem outro recurso senão a velocidade de progressão do filme (RONDEPIERRE, 2005a, p. 82, tradução do autor). 


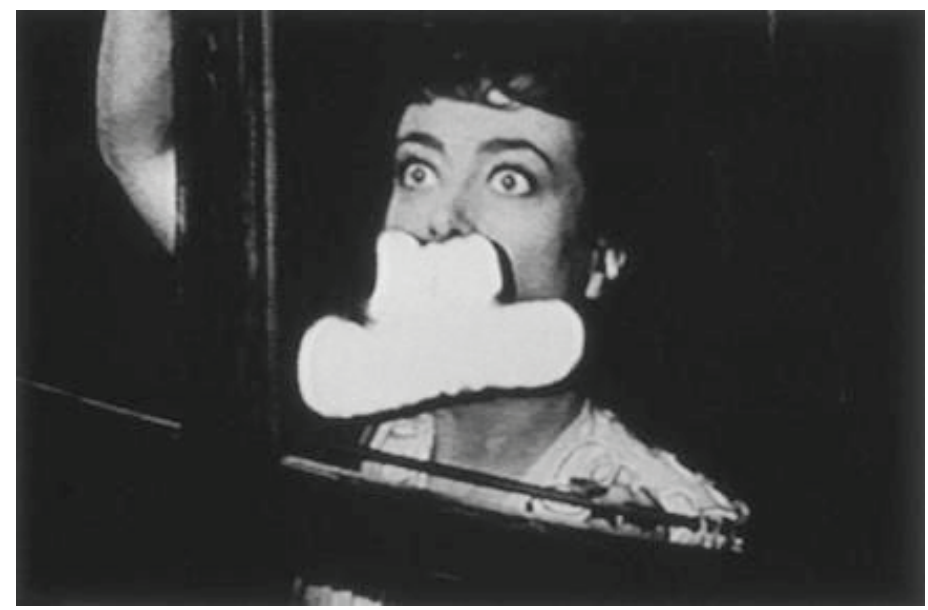

Figura 1:

Above Suspicion, da série "Annonces", 1993.

Fonte: Disponível em: <http:// www.parisphoto.com/agenda/ eric-rondepierre-cera-una-volta-il-cinema.> Acesso em: 9 abr. 2017.
O desvio proposital das clássicas partilhas do visível engendra instigante fantasmagoria. Um magma informe aparece no lugar estratégico da legenda, índice da face expressiva, compondo uma inflexão de sentido e de visualidade. Um figural, um acontecimento $d a$ imagem - tudo quanto funcione de modo intensivo, como mostra Dubois (2012, p. 104), para além (ou aquém) do figurativo ou do narrativo -, torna-se então protagonista indiciário do ficcional. No coração mesmo da narrativa, tem-se o que Colard (2003, on-line) interpreta como "o surgimento de um inter-dito", irredutível a toda denominação, rebelde a toda designação. Transportada da produção fotográfica ao romance, uma imagem por retenção (por efração?) "integra o dito e o não dito, a comunicação e seu impensado, a troca tanto quanto os silêncios e inibições que venham frustrá-la" (Colard, 2003, on-line). A figura é emblemática, sustenta Colard, ela "desvela os vazios, as falhas, as deiscências que não cessam de se nutrir no drama interno da imagem (Colard, 2003, on-line)". É pertinente falar de tropismos visuais, movimentos profundos e indefiníveis que se imiscuem rapidamente nos limites de nossa consciência. Eles bem conotam as anamorfoses dos olhos e da boca, esses dois orifícios que, como Rondepierre aprecia frisar a partir de Baudelaire, "contém a ciência do bem e do mal, o riso e as lágrimas”. Sua obliteração pelo que Colard (2003, p. 13) chama "formas ectoplasmáticas mais ou menos inquietantes", faz emergir à superfície, como leituras sugestivas, uma cenografia de traumas, de distensões aterradoras ou extáticas, de suspensões rumorosas. A imagem revela-se assim metaforicidade primeira da textualidade romanesco. 
Nessa composição de texto e imagem, que não deixa de evocar o fotorromance, poder-se-ia trabalhar com uma hipótese de fundo: a obra de Eric Rondepierre não procede do cinema - sua origem profunda, matricial, seria, antes, a literatura. Literatura que instauraria no que concerne o poder narrativo de toda imagem uma "era da suspeita”. Sentimento que se confirma ao leitor de La Nuit Cinéma. À figura de Crawford, apenas evocada, vem se acrescentar, imagem efetivamente disponibilizada, um clichê da série de 1993-1995 Précis de décomposition-Masque (fig. 2), um velho ator com os olhos obstruídos pela massa branca e informe de signos ainda indecifráveis. Assim, dois rostos-imagens com a boca e os olhos obstruídos por não ditos informes vêm justamente emblematizar o emperramento da ideia de continuidade narrativa como dimensão do imaginário. Outrora lugar de identificação, a personagem é doravante, à semelhança dos documentos fotográficos exumados, um "território devastado", "uma sombra”, uma "desfiguração” (COLARD, 2003, on-line), alvo primeiro de todos os atentados, base de todas as incertezas, campo de angústias, presa de uma vida interna que se faz "somatizar e se deformar a olhos vistos" (RONDEPIERRE, 2005a, p. 10-11).

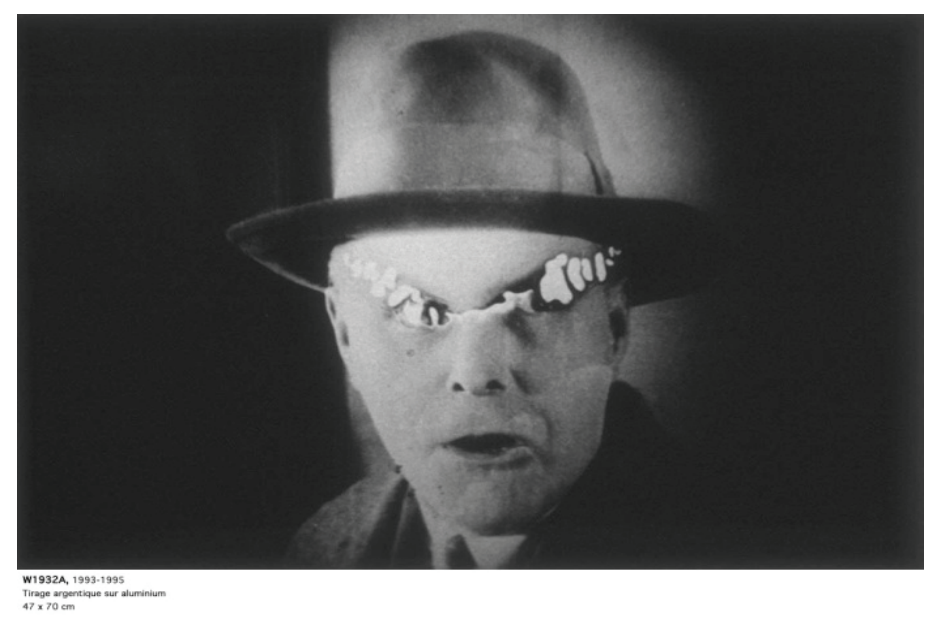

Assim, as interioridades que transitam pela narrativa não mais se enunciam por um "subtexto" hermeneuticamente legível, mas, ao contrário, sob a forma de um "sobretexto" (um infratexto?) tornado doravante perfeitamente ilegível. Nessa nova configuração em que a "vida subterrânea" irrompe no primeiro plano da imagem, o tropismo não é mais um
Figura 2:

W1932A, da série "Précis de décomposition”, 1993

Fonte:Disponível em:<https:// www.ericrondepierre.com/ oeuvres.html>. Acesso em: 9 abr. 2017. 
fato de linguagem, mas fenômeno visual feito da dissolução das letras, da deformação das palavras, da anamorfose dos títulos. Os tropismos não são mais palavras claramente articuladas e escritas, mas, aquém da linguagem, uma matéria maleável e plástica.

Sobre essa matéria, lugar por excelência do cruzamento do ficcional e do fotográfico, Rondepierre fala como que de uma "beleza misteriosa", efeito da acidentalidade que a caracteriza, bem como da indistinção que promove. A substância física do filme colabora com o drama ficcional nela gravado de modo a criar novas identidades. A película como matéria alia-se à ficção para dar novo "rosto" à imagem. Mesmo porque, insiste Rondepierre, o acaso e o trabalho do tempo dela participam, de tal modo que se torna difícil distinguir entre o devido ao acidente e o devido à intencionalidade imageante. $\mathrm{O}$ fato advindo da heurística assume valor de epifania: "agora compreendia o fruto do acaso e da inteligência; mas, para além do conceito que lhes dera um novo status perante meus olhos, olhei para as fotografias em si mesmas, nesse preto e branco acinzentado que as fazia aparecer tal como fantasmas" (RONDEPIERRE, 2005a, p. 23).

\section{Um olhar no reverso das coisas}

Olhar as fotografias "em si mesmas". Olhá-las na materialidade de seu suporte, ali onde se tramam as intrigas entre o acaso e o proposital, entre o real e seus simulacros. Olhá-las com um olhar que se reflete. O narrador carrega uma clandestinidade no interior de outra clandestinidade, no ato mesmo de afrontar o interdito segundo o qual "a fotografia (o fotograma) seria a irmã inimiga do cinema" (RONDEPIERRE, 2005a, p. 55). Mais que afã de contestação, há aqui um espírito de desvio no intuito de "contemplar o reverso das coisas". Seu espaço de evolução entende-se, aliás, elusivo, impreciso, como daquele que lê um livro pelas margens, no menosprezo pelo que soa decisivo; como daquele que se implica num percurso casual, tortuoso pelos "fundos de gaveta dos trabalhos microscópicos". Modo de romper, por autodefesa, com o "ronronar coletivo e inibidor" da imagem dominante; modo de escapar ao espetáculo como fuga de si mesmo; opção conseqüente por "operar na periferia [...], nas bordas"; por se contentar enfim com "o mínimo de imagem possível: uma superfície preta retangular, com um fragmento de frase branco" (RONDEPIERRE, 2005a, p. 57-6o). 
Aquele que se sente "designado por esse espaço indefinido de deserção" multiplica as tentativas de um "encontro aventuroso com a face", cuja "violência brutal" tende a se manifestar na "brusca passagem, sempre possível, da ficção (as costas) à realidade (a face)" (RONDEPIERRE, 2005a, p. 61). Virar a cara, procurar as costas; negar a face como uma estratégia - tanto mais paradoxal por ser ato de um fotógrafo para evitar, por fim, todo face a face com o real. Como lembra com justeza Marie José Mondzain (2003), a propósito do que diz ser a opção pela frequentação de uma "matéria profundamente noturna", "ver e mostrar responde a desejos que têm mais a ver com a nuca das coisas do que com sua face, com um desejo sem objeto do que com o desejo de saber". Em sua persona romanesca, Rondepierre confirma essa predisposição a seguir os rastros de algo irredutível, "sem rosto e sem esperança", a "ater-se ao dorso de tudo", a "liberar de toda face, inclusive da nossa, remetendo costas com costas o face a face entre nós mesmos e todos os outros, em nós e alhures" (RONDEPIERRE, 2005a, p. 61).

Essa persona de olhar enviesado, que atua "na periferia do espetáculo", constrói-se como figura exorbitada pelas coisas furtivas dos fundos de arquivos, ou então por aquelas alteradas, corroídas pelo tempo, iscas para um trabalho conjunto do acaso e da inteligência. Um trabalho "ao nível da morte", assume Rondepierre (2005a, p. 90), em "zonas que se furtam ao olhar do espectador", um engajamento na intermitência do visível, e "o prazer puro e simples de ver algo desaparecer" (RONDEPIERRE, 2001, p.65). A narrativa de Rondepierre parece guiada por esse paradoxo: "o surgimento do desaparecimento". O narrador atravessa o romance em combate contra alguém que não conhece, em cenas de dimensões oníricas, por vezes teatrais (traindo certo caráter lúdico), irônicas, onde as silhuetas estão sempre na iminência de desaparecer. Se um "surgimento do desaparecimento" é encontrado no trabalho fotográfico de Rondepierre, ele é objetivo igualmente do narrador que se deixa captar pelos buracos, pelas falhas, pelas intermitências no interior do filme - momentos de aberração visual, acidentes da imagem invisíveis a olho nu. Ele contenta-se em ser fascinado por essa dimensão paradoxal e provavelmente insignificante aos olhos de seus companheiros: o surgimento do desaparecimento. Não é, pois, por acaso que o artista se assume comumente como um "intermitente do espetáculo" (RONDEPIERRE, 2005b, on-line). 
Deter a imagem é reter o olhar junto ao que ele habitualmente atravessa. Eis um engajamento de admirável singularidade. Mais que a expressão de uma transparência opaca tendo adquirido visibilidade, trata-se de uma extrapolação do cotidiano dos hábitos escópicos. Trata-se da travessia de cada imagem, exumada, desventrada, quiçá cruzada por outras imagens, no excedente das mortes e dos renascimentos que povoam toda imagem. Assim, na hipótese que essa imersão refira um olhar reflexivo, olhar de si, diga-se que o artista Rondepierre atravessa, igualmente, seu próprio olhar diante da imagem cinematográfica a fim de passá-lo sob o crivo da escrita literária, passível de opacificar o que insiste em transparecer entre o olhar e a imagem. A posição de clandestinidade parece ser a única que convém a um narrador assim engajado. Ela transparece mesmo certa condição paradoxal do artista em geral.

Transgredir em um lugar protegido: o mundo da arte. O narrador não é um artista, nem o fotógrafo, mas ele ocupa essa área. As costas das coisas interessam-no desde sempre; ele revela as suas, mas de frente. Não devemos esquecer que é um comediante na origem, portanto, sujeito ao famoso paradoxo. Sua situação mesma de homem do subterrâneo é paradoxal. Ele é um pouco como essas imagens que coleciona, protegido em um porão, mas em situação extrema e arriscada: seja como for, é a guerra (RONDEPIERRE, 2005, on-line, tradução do autor).

Essa intencionalidade dilacerada que se compraz na escuridão e na clandestinidade - no olhar as costas das coisas, não tendo o mundo pelas costas -, de modo a deter o fluxo das aparências (dos mortos e dos ressurgidos), procura por seus traços característicos. De imediato, por meio de uma metáfora: "somos todos olhos do mesmo sonho". E pela conseqüente injunção: fechar os próprios olhos para "despertar e escutar o ruído do sonho". É o que entende fazer o narrador com as imagens, esses "agentes adormecidos" que ele recorta das películas. Se há o empenho em despertá-las, a tarefa não se propõe redentora. "Tenho a cor do vazio", ele confessa (RONDEPIERRE, 2005a, p. 70). Mesmo porque imiscuir-se nas imagens, em sua labilidade, é estratégia de resguardo que reconduz ao coração da questão contemporânea dos regimes evocativos e/ou indiciários do olhar e da imagem. Nos termos de Rondepierre (2005, on-line), entre uma ou 
outra reminiscência pessoal, a respeito de seu narrador: "o que ele profundamente desejou não pode aceitar; poderia se trespassar os olhos como Édipo, mas prefere olhar diante de si. Mas, justamente, diante é detrás: lembro uma noite, na Eslovênia etc".

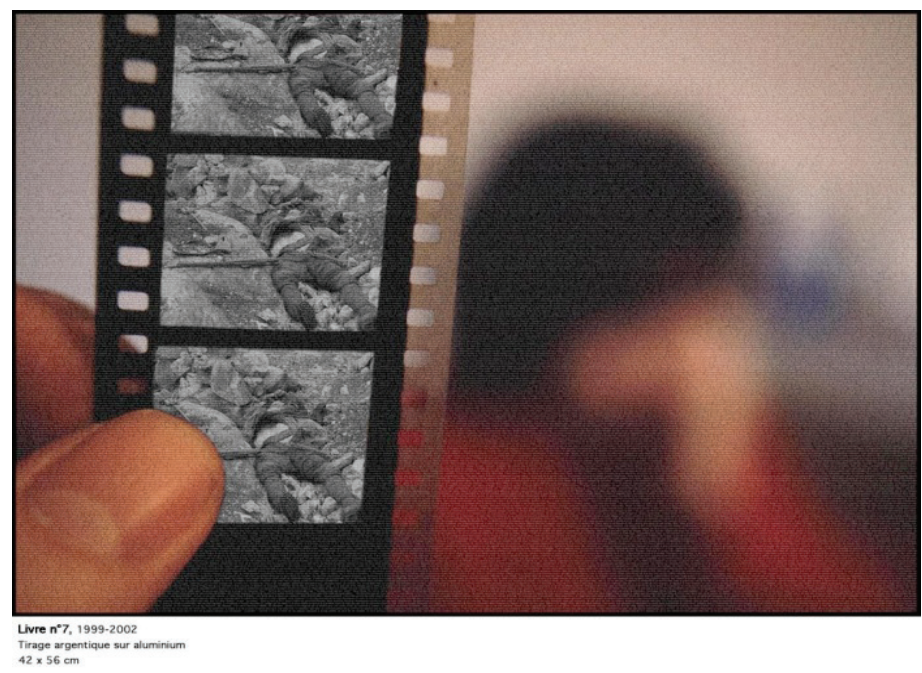

O filme é para o narrador um corpo a ser desnudado, dissecado, metáfora recorrente no romance. Rondepierre propõe o mesmo para a escrita? A posteriori, seria possível assumir que a escrita de seu livro segue o caminho inverso daquele do narrador. Este vai direto ao corpo da imagem, eliminando a ficção que a vestia. Contrariamente ao escritor, que dispõe de um corpo a ser investido de ficção de modo a dar-lhe sentido através de um imaginário que é o seu. Fato é que a escrita e a fotografia são para o autor de La Nuit Cinéma duas práticas indissociáveis. Não basta dizer que o texto acompanha de uma maneira ou de outra o trabalho com a imagem. Ou lembrar que Rondepierre (2001, p. 55) há tempos afirmou a necessidade de "construir uma ficção para se fazer compreender" em seu trabalho de artista da fotografia. Fato é que a textualidade de La Nuit Cinéma já se prestou como matéria a pixelização de uma fotografia - na série Loupe/ Dormeurs (1999-2002) (fig. 3) -, onde ela figura como uma trama textual, uma escritura branca feita de 156 mil signos minúsculos, sobre um fundo desfocado. A composição, à evidência, obriga o espectador a bascular ininterruptamen-

\section{figura 3:}

Livre nำ, da série "Loupe/Dormeurs", 1999-2002

Fonte: Disponivel em:< https:// www.ericrondepierre.com/ oeuvres. html >. Acesso em: 9 abr. 2017. 
te da visão à leitura, da nitidez em primeiro plano ao plano de fundo em suspensão, entre elementos heterogêneos (a guerra e o amor; o real documentado e a ficção documentada) que se contaminam mutuamente numa inevitável irresolução do olhar. Essa imagem, na tensa e protendida narrativa que carrega, é tão somente o início de um projeto que propõe inserir numa só fotografia a produção de décadas. "É somente então, sustenta Rondepierre (2010, on-line), que eu atingiria a matéria que me convém, a medida não comum entre texto e imagem, atingindo seu cúmulo e formando aquele bloco de tempo ilegível e invisível que todo ser humano deposita em algum lugar antes de partir".

\section{Escrever a decomposição do fotográfico}

Talvez se possa então estimar o tom onírico da narrativa de La Nuit Cinéma, a osmose estranha, labiríntica que nessa se propõe entre o real e o imaginário, cujo equivalente mais próximo parece ser a narrativa do sonho. Ou, mais precisamente, a narrativa do que precede qualquer entendimento desse sonho: os hieróglifos, o rébus do sonho. Não é por acaso que Rondepierre (2001, p. 76) entende "escrever como se desperta, quando o cérebro é ainda algo por vir, algo não presente". Assim como o sonho não se traduz simplesmente pela língua do analista, La Nuit Cinéma não deve ser lida como mera transposição do fotográfico ao ficcional. Como observa Michelle Debat (2003, on-line), ali onde a fotografia dá-se brutalmente, o imaginário se exclui; ali onde o texto faz imagem, ele encontra pretexto para trabalhar. Ocorre que "fazer imagem" impõe certa motivação à indisposição. Uma "raiva surda e cega do espetáculo", a necessidade de silenciar o mínimo "eco narrativo" (RONDEPIERRE, 2005a, p. 66), diz muito de um jogo de tromperie, modo de contornar a transparência retórica. A empresa de decomposição do fotográfico, se ela tem seu contraponto na escrita, tal acontece ao se inscrever numa problemática de liberação da ordem do discurso, de seu "direito de olhar", de velar pela eficácia própria ao visual. Ao afirmar que "a imagem como tal" é constituída de uma subtração da narrativa pelo fato material, Rondepierre desloca o velho dispositivo de submissão da imagem ao processo verbal de uma narração, ao enunciado claro de uma história. Contra essa transparência retórica - que triunfa no cinema e cujo dispositivo original é mimetizado pelo aparelho fotográfico -, ele entende "despertar" 
a imagem, "nela conservar o gosto da potência", deixar advir "outras possibilidades de narrativa na narrativa" (RONDEPIERRE, 2001, p. 125, 42, 60), fazendo aflorar a força latente do material de que é feita. A imagem, então, não mais deve ser procurada sobre um suporte; é o suporte, o material, a ser doravante apreendido na imagem; é ele que a trabalha do interior. De pernas para o ar, diante, por detrás, se os planos se invertem, se os ângulos tornam indecidíveis as narrativas - viés mais que evidente da obra fotográfica de nosso autor -, então entende-se que Rondepierre termine por reivindicar uma espécie de retórica da indefinição:

Se procurei contar uma história confusa, aproximativa, foi ainda por fidelidade à retórica, permanecendo escondido, como é justo que seja, com as minhas chagas. Espero mesmo recuperar algum benefício proporcionando-me um pouco de dificuldade, mas estou cada vez menos em situação de mobilidade. Poderia também furtar-me à tarefa se não pensasse ser o objeto de uma particular designação. Enfim, presumo que o passado ainda me dará a matéria de um presente projetado para o futuro. A imobilidade e o escuro, um pouco de movimento e de luz. Mas isso é tão certo assim? Estaria maduro para a recuperação? Um passo à frente? Os bombardeios não recomeçarão? Devemos levar a sério essas calmarias? Quando tudo isso irá de fato acabar? E haverá uma continuação? (RONDEPIERRE, 2005a, p. 155, tradução do autor)

Segue-se, a guisa de desenlace, um monólogo da instância narradora em torno de sua (in)habilidade em "testemunhar sobre as zonas obscuras". Mesmo Eva, paradigma feminino, surge, derradeiramente, por insistência do olhar, como aproximação distante. Uma figura romanesca tênue, insinuada ao longo do livro, a lembrar, uma vez mais, que no fotógrafo punge uma forma intermitente. De fato, a imagem da mulher aparece e desaparece. Ao final, resta somente sua fotografia ... e a clandestinidade de um olhar. "A vertigem de uma forma sem conteúdo" emblematiza o narrador em seus impasses e contingências; e aponta, inquivocamente, para o sujeito de olhar fotográfico debruçado sobre os documentos fílmicos: "ao contrário, de lado, jamais de frente" (RONDEPIERRE, 2005a, p. 47). Ora, o ato de decompor a película "desvestir o filme, retirar sua couraça temporal, pô-lo a nu, tocar seu corpo" - revestia-se dessa conotação: tratava-se de 
deter um espetáculo, um corpo coletivo. Donde a interrogação terminal: "no fluxo de consciência planetária unificada, na nova ordem numérica mundial, e a partir dela, como abrir uma fresta, introduzir uma zona de silêncio que seja também uma singularidade de consciência?" (RONDEPIER$\mathrm{RE}, 2005 \mathrm{a}, \mathrm{p} .162$ ). Isolar um fotograma permanece resposta pessoal à voz hegemônica do cinema. Assim como recolher uma vida desprovida do menor sentido, tornada mancha em um pequeno retângulo de celulóide. A ausência de imagem, seu desaparecimento, aquele do movimento nas escuridões, o "surgimento do desaparecimento", aponta de certo modo a um júbilo junto ao caos que acomete por fim toda imagem.

Muito a propósito, uma descrição de fotografia fecha um romance dedicado às vicissitudes da imagem. A figura feminina ressurge, fantasmática, depositária daquela intenção prospectiva que uma centena de páginas atrás marcara a aspiração maior da narrativa: apreender a "fração de segundo queimando no interior de todo homem" , assemelhada à "grande nudez do instante"( RONDEPIERRE, 2005a, p. 76).

[...] sei que ao observar esse pedaço de papel libero algo de mim mesmo. Sinto a fotografia brilhar para mim com toda a potência de um recurso. Poderia vê-la por horas a fio, não avançaria uma polegada em seu segredo. A consciência que tenho desse impasse só fará obstáculo ao que ela me transmite. O que? Que Eva não está mais ai para me responder? Que ela estava ciente da objetiva voltada sobre ela? Que ela posou desde seu despertar? Sem dúvida. Pelo menos gosto de pensar nisso, de experimentar a profundidade visual dessa constatação e o brilho das coisas atravessadas que nela se deixam ver (RONDEPIERRE, 2005a, p. 168, tradução do autor).

Na refutação do poder indiciário da fotografia, que provoca "a suspensão do tempo", nota-se a afirmação de seu contrário: a ausência irremediável, "o vazio de uma presença”. E a consequente deslegitimação de todo esforço de estocagem e restauração das imagens, em favor da intencionalidade de "deslocá-las", de "furtá-las", de "virá-las e escrever sobre suas costas". "Cada imagem negra”, estatui Rondepierre (2010, on-line), "é uma reunião de vontades que se ignoram". Razão porque sua persona romanesca experimenta, por fim, a necessidade de escapar ao circulo infernal das narrativas e dos corpos que mobíliam, no escuro do cinema, o imaginário. Extinção inevitável do passado, sem culpabilidades. Não mais 
imagem, mas alguns signos amorfos, em branco, capazes, quiçá, de deslocar os limites do espetáculo, por força mesmo da face fantasmática que teima em colar à figura do sujeito de olhar noturno.

\section{Referências}

ARASSE, Daniel. Des images de rêve. In: Eric Rondepierre. Paris: Léo Scheer, 2003, p. 19-26. Disponível em:< https:// www.ericrondepierre.com/download/des-images-de-reve.pdf>. Acesso em: 25 mar. 2017.

BERTHOU CRESTEY, Muriel. De la transparence à la "disparence": le paradigme photographique contemporain. Revue Appareil, n. 7, 2011. Disponível em: <http://revues. mshparisnord.org/appareil/pdf/1212.pdf>. Acesso em: 25 mar. 2017.

CARON, Muriel. Eric Rondepierre. Critique d'art [on-line], 23, 2004. Disponível em: <http://critiquedart.revues. org/1756>. Acesso em: 26 mar. 2017.

COLARD, Jean-Max. Photo-Tropismes. In: Eric Rondepierre. Paris: Léo Scheer, 2003, p. 65-71. Disponível em:<https:// www.ericrondepierre.com/download/jean-max-colard-. pdf\%3E.>. Acesso em: 26 mar. 2017.

DEBAT, Michelle. Pour voir ... ! quoi?, photographies d'Éric Rondepierre, 2003 . Disponível em: <hhttp://www.exporevue.com/magazine/fr/rondepierre.html>. Acesso em: 28 mar. 2017.

DUBOIS, Phillippe. Efeito filme: figuras, matérias e formas do cinema na fotografia. In: SANTOS, Alexandre; SANTOS, Maria Ivone dos. A fotografia nos processos artísticos contemporâneos. Porto Alegre: Ed. UFRGS, 2004.

.Plasticidade e Cinema: a questão do figural. In: HUCHET, Stéphane (Org.). Fragmentos de uma Teoria da Arte. São Paulo: Edusp, 2012, p. 97-118.

. Eric Rondepierre ou le photogramme dans tous ses états (entre la tache et la trame). In: Eric Rondepierre. Pa- 
ris: E. Espace J. Verne, 1993. Disponível em: <http://www. ericrondepierre.com/pdf/philippedubois.pdf $>$. Acesso em: 24 mar. 2017.

FERREIRA, Beatriz Rodrigues. O tempo criador: análise da poética da decomposição na obra fotográfica de Éric Rondepierre, 2008. Disponível em: < https://www.yumpu. $\mathrm{com} / \mathrm{pt} /$ document/view/12765675/o-tempo-criador-analise-da-poetica-da-revista-poiesis >. Acesso em: 15 mar. 2017.

LENAIN, Thierry. Iconologie de la décomposition. In: Eric Rondepierre. Paris: Léo Scheer, 2003, p. 105-113. Disponível em:< http://www.ericrondepierre.com/sparkle_backups/ sparkle_backup_20161015134108/pdf/thierrylenain.pdf > . Acesso em: 24 mar. 2017.

MONDZAIN, Marie José. Une histoire matérielle du regard. In: Eric Rondepierre, Paris: Léo Scheer, 2003. Disponível em: <https://www.ericrondepierre.com/download/marie-jose-mondzain.pdf >. Acesso em: 7 abr. 2017.

RIOUT, Denys. L'ombre des images. In: Eric Rondepierre. Paris: Léo Scheer, 2003. Disponível em:<https://www. ericrondepierre.com/download/denys-riout.pdf $>$. Acesso em: 27 mar. 2017.

RONDEPIERRE, Eric. Apartés. Trézélan: Filigranes Editions, 2001. p. 144.

. Entretien avec Eric Rondepierre, par Isabelle Rozenbaum [online]. 2010. Disponível em: <http://d-fiction. $\mathrm{fr} / 2010 / 03 /$ entretien-avec-eric-rondepierre/> . Acesso em: 27 mar. 2017.

. Eric Rondepierre. Paris : Léo Scheer, 2003, p.189.

RONDEPIERRE, Eric. La Nuit Cinéma. Paris: Seuil. Coll. Fiction \& Cie, 2005a. p.172.

La Nuit Cinéma. Entrevista com Éric Rondepierre, por Lise Beninca. Le Matricule des Anges, n. 62, abril 2005b. Disponível em: <http://www.lmda.net/din/tit_ lmda.php?Id=22241 >. Acesso em: 28 mar. 2017. 
. Oeuvres. Disponível em: <http://www.ericrondepierre.com/pages/fr_oeuv.html>. Acesso em: março/abril 2017.

RONGIER, Sébastien. Eric Rondepierre, La Nuit Cinéma. Une revue, 2005. Disponível em: < http://remue.net/spip. php?article $562>$. Acesso em: 22 mar. 2017. 
Recebido em: 07/05/2016

Aceito em: 20/03/201

\section{OSVALDO FONTES FILHO}

\section{osvaldo.fontes@unifesp.br}

Doutor em Filosofia pela USP e pós-doutor pela UNESP, desenvolveu pesquisas nas áreas de Filosofia da Arte e de Ciências da Linguagem na Université François Rabelais de Tours/França e no Centre d'Histoire et Théorie de l'Art da E.H.E.S.S./Paris. É autor, entre outros, de MerleauPonty na trama da experiência sensível (Editora da UNIFESP, 2012) e tradutor/prefaciador de Georges Didi-Huberman, A Pintura Encarnada (Escuta \& Editora da UNIFESP, 2012). Endereço: Rua Iperoig 714, apto.112, Perdizes. São Paulo/SP. CEP o5016-ooo Instituição: Departamento de História da Arte da Escola de Filosofia, Letras e Ciências Humanas da Universidade Federal de São Paulo 